\title{
TOWARDS AN AFRICAN THEORY OF JUST WAR
}

\section{Hacia una teoría africana de la guerra justa}

\author{
LAWRENCE OGBO UGWUANYI \\ University of \\ Abuja (Nigeria) \\ lawrenceogbougwuanyi@gmail.com
}

Recibido: Julio 2020; Aceptado: Noviembre 2020

Cómo citar: Ugwuanyi, Lawrence Ogbo (2020) "Towards an African theory of just war", Revista de Estudios Africanos, Número 1, páginas 51-65.

https://doi.org/10.15366/reauam2020.1.003

\begin{abstract}
From 1957 when the first independent country emerged in Africa till date, Africa has fought over a hundred wars ${ }^{1}$. These wars which have been both inter-state and intra-state wars, sometimes called civil wars, provoke philosophical questions on the meaning and notion of war in African thought scheme. Were these wars just or not within an African conception of war- that is the means, manner and method of fighting war within the African experience? If the idea of just war were advanced through the African worldview, what principles would define it? What alternative and fresh values would be suggested by the theory? This article sets out to address these questions. To do this, the work will attempt to articulate an African theory of just war by mapping out what it would look like if it were informed by the norms, values, and micro-principles that characteristically drive philosophical enquiry in an indigenous African context. The work will draw from narratives about wars that have been fought in traditional African society as well as oral texts to achieve its position, which is roughly that a just war in African thought is war fought to protect the corporate harmony of a people who are bound and bonded together through land, the resources, and other symbols and traditions that make them distinct.
\end{abstract}

Keywords: Africa, just war, theory, principles, values, harmony.

\section{Resumen}

Desde 1957, cuando accedió el primer país africano a la independencia, hasta la fecha, África ha librado más de cien guerras. Estas guerras que han sido tanto interestatales como intraestatales, a veces llamadas guerras civiles, suscitan preguntas filosóficas sobre el significado y la noción de guerra en el esquema de pensamiento africano. ¿Fueron estas guerras justas o no dentro de una concepción africana de la guerra, esto es, según los medios, la manera y el método de librar la guerra dentro de la experiencia africana? Si la idea de la guerra justa se concibiera en el marco de la cosmovisión africana, ¿qué principios la definirían? ¿Qué valores alternativos y nuevos sugeriría la teoría? Este artículo se propone abordar estas cuestiones. Para ello, intentará articular una teoría africana de la guerra justa trazando un mapa de cómo sería si estuviera informada por las normas, los valores y los microprincipios que caracterizan la investigación

\footnotetext{
${ }^{1}$ These wars are recorded in a number of literature in social science and history discourse in Africa. The wars include 1957-1958 Ifni War; 1963-1967 Shifta War; 1964 Ethiopian-Somali Border War; 19641979 Rhodesian Bush War; 1965-1979 First Chadian Civil War; 1966-1989 South African Border War; 1967-1970 Nigerian Civil War; 1975-1991 Western Sahara War; 1972-1974 First Eritrean Civil War; 19741991 Ethiopian Civil War; 1975-2002 Angolan Civil War; 1977-1992 Mozambican Civil War; 1977 Libyan-Egyptian War; 1978-1979 Uganda-Tanzania War; 1980-1981 Second Eritrean Civil War; 1982 Ndogboyosoi War; 1982 Ethiopian-Somali Border War; 1983-2005 Second Sudanese Civil War; 1989-1991 Mauritania-Senegal Border War; 1989-1997 First Liberian Civil War; 1990-1994 Rwandan Civil War; 1991-1994 Djiboutian Civil War; 1991-2002 Sierra Leone Civil War; 1991-2002 Algerian Civil War; 1993-2005 Burundian Civil War; 1993-1994; Republic of the Congo Civil War; 1996-1997 First Congo War; 1998-2000 Eritrean-Ethiopian War; 1998-2003 Second Congo War; 1998-1999 GuineaBissau Civil War; 1999-2003 Second Liberian Civil War, etc.
} 
filosófica en un contexto africano indígena. El trabajo se basará en narrativas sobre guerras que se han librado en la sociedad africana tradicional, así como en textos orales en apoyo de nuestra tesis, a saber, que una guerra justa en el pensamiento africano es una guerra librada para proteger la armonía corporativa de un pueblo que está vinculado y unido a través de la tierra, los recursos, así como otros símbolos y tradiciones que lo hacen distinto.

Palabras clave: África, guerra justa, teoría, principios, valores, armonía.

\section{INTRODUCTION}

The literature that addresses the question of war in Africa has largely ignored the need to apply the idea of just war in relation to African thought. Indeed, apart from recent efforts to address the subject of war in Africa through philosophical research such as Okeja (2019) and Metz (2019) and Lucius Cordeiro-Rodrigues (2018), the majority of the literature are done by historians ${ }^{2}$ and not philosophers. But the philosophical engagement of these scholars (perhaps with the exception of Okeja) also creates gap for more efforts which this study sets out to fill. Their efforts favour the application of few ethical principles in relation to war in African thought and are majorly shaped by narratives drawn from South African experience. They do not make broad appeal to the wider precolonial wars in Africa.

Similarly, the historians, do not provide alternative to philosophical study on war in African thought as their researches favour their discipline majorly. While Uzoigwe (1974, 1975), Ukpabi (1972, 1974), Crowder (1971), Smaldone (1975) dwell on issues that relate to or derive from war, such as prevention of war, conflict resolution and mediation, Ogot (1972), Ajayi \& Smith (1971), and Awe (1973) dwell on the sociological aspects of war in Africa by discussing the nature and type of military organisation, the nature of execution of wars, the economy of warfare, the nature of military technology and the goal of warfare in Africa. Similarly, Ukpabi discusses the "types of military organisations" (p. 200), "effects of the military on traditional societies" (p. 294), and "the role of women, slaves and mercenaries in traditional armies" (p. 206).

In the historical studies, there are observable conflicts in the claims made therein. Uzoigwe (1945:471) cites Johnson and draws instance from the Ibadan wars in pre-colonial Nigeria to argue that "there never was or has been a standing army, nor any trained soldier (except at Ibadan latterly where the idea began to germinate)." But this view is however contradicted in another part of the work when the author talks of the Abarusura group in the Kitara Empire of East Africa, which are equivalent to a "standing army" (op. cit. p. 473) and through which the king "was able to wage a long guerrilla campaign against the British in the last decade of the nineteenth century" (ibidem p. 473).

This work is not motivated by the desire to resolve this controversy or related ones. What the work has set out to do is to provide a philosophical study of wars in Africa with the aim to explore the principles on which these wars were held to be just or unjust. To achieve that, the work will address the following question: assuming that the idea of just war is advanced through the African worldview, what would it look like -what alternative or fresh values would be suggested by the theory? To answer the question the work will provide the idea of just war in African thought by locating the principles and values that drive wars in the African context. It will do so by discussing these wars; the

${ }^{2}$ The historians include Uzoigwe (1974, 1975), Ukpabi (1972, 1974) Ogot (1972), Crowder (1971) and Smaldone (1975). Others include Irozu (1977), Alagoa (2001), Ugochukwu (2006), Brukum (1998), Francis (2006), Ajayi \& Smith (1971), Awe (1973), Karugire (1972), Webster (1972), etc. 
means and methods through which they were fought and the reasons for which they were fought, the values that they defended, and how they can be distinctly called African.

The work is unique in drawing from a number of narratives on wars in traditional African societies and, in the light of them, developing principles of jus ad bellum and jus in bello in the African context. This, I believe adds fresh literature on the discourse on war in Africa because it goes beyond modern warfare in Africa to draw its inferences. The work does not claim that all wars fought in traditional Africa were just wars in the African context or seek to re-invent the myth of romantic innocence that suggests the traditional African world was devoid of crisis and wars. What it does is to articulate and analyse the conduct of the wars in traditional African society and the beliefs behind them, to locate the possible values that guided them and proceed from there to illustrate how these lead to a fresh approach to just war in the African context. The work will first (i) discuss the substance of African worldview and the extent to which it favoured warfare. Thereafter, it will (ii) discuss the idea of just war in Africa by looking at (iii) the nature of war in Africa. Based on (i), (ii) and (iii) the work will (iv) proceed to articulate the principles of warfare in Africa and the theory of just war implied. Although a number of references will be made to other ethno-cultural groups in Africa, my work will draw significant views and positions from the Igbo for the study. The application of the Igbo for this is for a number of reasons. The first is that the Igbo is an ethno-cultural group in Africa that exhibited no expansionist drive. Based on this Igbo wars provides illustrations of just wars in line with the assumption of the work that such war must aim at the corporate harmony of the group with no expansionist drive. The second reason is that this scholar is considerably familiar with Igbo life and thought and have carried a number of studies on this thought scheme (Ugwuanyi $(2006,2008,2020)$ and could volunteer views that can be credible and authentic about the Igbo world.

\section{LOCATING AN AFRICAN THEORY OF JUST WAR THROUGH THE SUBSTANCE OF THE AFRICAN WORLDVIEW}

A just war is a war fought for the purpose of maintaining justice. It can also be defined as a war fought for a just cause or a war fought as the only means to claim rights. Many of the literature on just war are driven by the Western notion of the idea, and do not account for alternative conceptions of it. Recent literature on the topic include Luís Cordeiro-Rodrigues and Danny Singh (2019), Jeff McMahan (2009), Thomas Hurka (2008), Larry May (2004, 2008), (2004), Gregory Reichberg (2008), Dower (2009), Brough et al. (2007), Patterson (2007) and Harry (2007). Among these works, Luís Cordeiro-Rodrigues and Danny Singh (2019) can be singled out as the text that has considered alternative conceptions of just war. This is because the work is a collection of studies on just war that engages this topic in an international setting.

But this method, which scantly focus on alternative notions of just war, is inadequate. This is because justice, just cause and rights are concepts that are contextually driven in the sense that they are defined and defended through distinct/different worldviews. While justice conceived here as right actions is desired and cherished in all cultures, what this means and the grounds through which actions are held to be right could differ. Thus, to see whether the idea of just war anchored on a particular worldview could be valid would be appealing. This effort will provide alternative notions of the idea that can be applied to modify existing documented notions on just war. Austin Fagothey in his popular work Right and Reason (1963) advances a claim that a just war should be declared by the state:

The state, since it is a natural society, has from the natural law, the right to use the "means necessary for its preservation and proper functioning". But conditions may be such that the only means by which a state can preserve itself in being, and can protect or recover 
its lawful rights, is by war. Therefore, under such conditions, the state has from the natural law the right to wage war (Fagothey 1963: 653)

What we can read from this position is that just war should be approved because it emanates from the right to self-defence which in itself is a natural right. Thus the states itself being a natural society should exercise this right of self-defence. But whether the state is a natural society in all instances is debateable and whether the right to declare war can be conferred to all states is a debateable issue that is too broad to be addressed in this work.

Another western tradition of thought on just war draws significantly from the views of the scholastic philosopher St. Thomas Aquinas. According to this school of thought, four conditions are necessary for a just war to obtain. They are: (a) lawful authority, (b) just cause, (c) right intention and (d) right means. Following this tradition of thought (e) the distinction between combatants and non-combatants has been added as another item in recent literatures (Brough et al. 2007, Dower 2009). The condition of lawful authority implies that a just war must be declared by a legitimate and supreme authority. Such condition is required because just war should be held to promote the goal of the state and the good of the citizens whose wellbeing might be in danger without such war. But a legitimate authority should not just declare war and be indifferent to the prosecution of war. It should also supervise the war. The legitimate authority also has the duty to terminate the war when the situation demands that the war should be brought to a halt. But what happens when a state lacks constituted authority? Who should declare war at this time? This position suggests that in absence of a constitutionally elected authority such as during military regime, a just war could be declared by the de facto government.

The second principle that is demanded for a just war in western thought is (b) just cause. By just cause is meant that for a war to be a justified one, the cause must be such a grave one such as the violation of the nations' rights, the seizure of a nation's resources or treasury, or unjust claim to her lands. However, for a just cause, war can and should only be applied as the last resort. Possible peaceful avenues must have been applied. Diplomatic contacts, appeals to such organs as the United Nations Organisations and lesser measures such as economic sanctions, etc, must have proved abortive. Fagothey (1963: 504) supports this view with the claim that,

Before a nation takes to war, it must have exhausted every peaceful means consistent with its dignity: negotiations, meditation, arbitration, diplomatic pressure, economic sanction, ultimatums, and every other means known to enlightened statesmanship.

In view of the central role of justice in the notion of just war, the notion of justice implied deserve further elaboration. For a nation to be held to have a just cause (i) The nation's cause must be not only just but known to be just; (ii) There must be a sufficient proof that the war is unavoidable: other possible peaceful means must have been applied to avert the war but to no avail; (iii) There must be sufficient proportion between the good accomplished and the resultant evil, (iv) There should be the prospect of success that the war will solve the problem it is expected to solve. (Here, it is important to note that a just war may not of necessity be in favour of the party defending oneself but can serve as a resistance to the unjust aggressor and repel his aggressive force).

The third principle of just war in western thought is right intention. That means that a just war must be war declared with pure and proper intention. This intention is the realisation of just cause. If a war is waged for an unjust cause, the intention cannot be a right one. The view here is that only a war declared by a right intention (defined as one that is driven by the intention to realise a social, moral or political good that cannot be realised otherwise) should be permitted. Ordinarily, intention is held to be right when the outcome of the good that is meant to be realised through it can be held to be good. It is this notion of intention that is applied in this instance. This means that wars declared to revenge personal harm or for some selfish reasons are not just wars, just as, war fought for thirst for power is not a just war. 
The fourth principle of just war in western thought is (d) right means. A war must be fought in the right way for it to be just. Right means include weapons applied and the manner the weapons are used. For example, if a gun is applied to execute war but instead of applying the gun on the combatant it is rather applied to kidnap and torture children of the combatants, then the gun is a wrong means. A counter argument here may be: if the kidnapping or torture of the children should frustrate the ambition of the combatants, does it not serve the right means since it may lead to the defeat of the enemy? The answer is simple: that such use of gun is still a wrong means. This is because children are hereby made to be victims of war they did not vote for or elect to be part of. Here it is important to review the view that in war all is fair and to suggest that all cannot be fair in a war. If war is waged to secure and preserve lives of those within a state applying all measures to wage was such as those could also affect all citizens is wrong because this can defeat the entire goal of the war.

The fifth position that makes for a just war is the distinction between combatants and non-combatants. Combatants in a war are active participants in a war, such as the pilot driving the war plane, the soldier at the warfront. Non-combatants are people who do not fight the war or who may only be co-operating remotely in the military effort, such as those who cook for the soldiers in the warfront, and those who nurse their wounds, and the people that supply arms to the soldiers. Thus, a just war cannot wilfully approve the termination of the lives it is presumably meant to defend or those who are supposed to be the rightful beneficiaries of the war. Indeed, the distinction between combatants and non-combatants is one of the triumph of international law and a testimony to the advance of civilisation and this is clear from sanctions against defaulters through the International Criminal Court ${ }^{3}$.

These principles of just war have strong merits and have directed the morality of war for some time now, and recent literature have also elaborated and improved on them. Indeed recent literature have expanded the discourse and now locate them under three separate concerns: justness of war (jus ad belum), justness in the conduct of war (jus in bello) and just end of war (jus post bellum); (Brough et al. 2007, Dower 2009, Patterson 2007).

However, there is the need to interrogate these positions in relation to the nature of war in African thought scheme. In modern history, the African continent has arguably witnessed more inter-state and intra-state wars in the world than other parts of the world, and it is important to explore the ethics that underlie such wars and how just these wars could have been said to be. Many of these wars could have been fought on the ground that they are just wars. But could that have been the case, assuming that the African thought schemes were applied to evaluate these wars? Secondly it makes sense to look at the extent the concepts that have been applied to discuss the theory of just war, such as right authority, right intention, etc., can be applied to African thought. For instance given that the state has the sole authority to articulate, administer, and defend rights through the force of arms, and that the state has different forms and models, it makes sense to pose a pertinent question: what is the state in the African thought and on what grounds can the state be held to be one equipped to declare war? Which authority declares war in an African traditional state and on what ground is such authority held to be competent to do so? These questions deserve to be addressed and will be resolved, at least in part, by my work through the effort to formulate a just war theory based on African worldview.

\footnotetext{
${ }^{3}$ This position is illustrated by the provision of the International Criminal Court which in Rome Status of ICC 2187 Unit 90, Article 8, on War Crimes-viii-i declares that: Intentionally directing attacks against the civilian population as such or against individual civilians not taking direct part in hostilities; is part of war crime. Details can be found in https://libguides.bodleian.ox.ac.uk/c.php?g=422886\&p=2887806 (Accessed: November 2020).
} 
To articulate an African theory of just war, I begin by mapping out the substance of the African worldview and the idea of war implied. I do this because it is through this understanding that the principles that can approve war in African thought can be appreciated. Several scholars have made attempts to spell out the distinct principles that can be applied to capture the substance of African worldview. They include Mbiti (1970), Momoh (1989), Onwubiko (1991) and Onah (in Metz, 2007). These scholars outline such principles and values as (a) "sense of hospitality", (b) "sense of the sacred", (c) "sense of community" (d) "sense of good human relations", (e) "sense of identity", (f) sense of human value" and (g) sense of the past or an idea of time that is more relevant to the past as constitutive of what can be called the core values that define and regulate the African worldview.

In relation to this work, the crucial issue is to explore the extent to which a worldview that harbours these principles and values has a strong disposition towards the principle of war; that is, the extent to which it can be argued that the worldview of Africans has some basic inducements that could promote war. I submit that a worldview that harbours these principles would largely seek for principles that would lead to peace rather than those that would lead to war in the sense that war negates the moral and social demands of these principles. Indeed, none of these outlined values and principles can be promoted by war or can be held to be pro-war. To illustrate my position I elaborate these principles. Those who hold a sense of hospitality (a) would usually consider this value to have been realised by how much the other people to which this value has been offered would feel good at the end of the encounter, and a sense of hospitality cannot be achieved through war. Similarly, those who hold a sense of the sacred (b) would often have a sense of mystery through which this disposition to life expresses itself. Such sense of mystery would often be identified, at least in part, with human life. They would be attracted to the spiritual component of the human person such as soul and spirit, which can defy death and fight enemies back. For this reason, they discourage war, which results to the elimination of the human person. Those who believe in (c) a sense of community would often seek actions that bind and unite rather than those that create hatred and discord. For this reason, such acts as war, which represents hatred and promotes industrial enmity and hatred, would not be part of their social ethics (except, perhaps, when it becomes absolutely necessary to defend the community through this means). Indeed, they would often seek actions that promote solidarity and identity with other groups or communities (Metz 2007) and perhaps even fellowship, which are not achievable through war. A sense of human relations (d) would often wish for a platform for healthier communication and interaction through which the idea of inter-subjectivity can be enhanced. In a similar way, those who hold (e) a sense of identity would often wish to create a basis through which their identity would be located more ethically, as being positively different from the other person or group. Those who think this way would not encourage war as basic social ethics. In the African instance, there are reasons to suggest that sense of identity would often be sought through actions that promote a humane idea of the other. In African thought scheme, a host of concepts in African thought illustrate this disposition -among the Igbo of Nigeria, personhood has a strong moral content, part of which is a considerate and humane disposition. For such a person the Igbo ethnic group of Nigeria would say "o bu madu madu"-he is a complete person. Similarly, the Wolof of Senegal have concepts like "taranga", just as the Fulani ethnic group spread throughout West Africa have the concept "pulaku" and the Yoruba ethnic group of Nigeria apply the concept "omoluabi" to portray this principle.

In a similar vein, a sense of human value (f) would demand that a people do much to secure human life, which is implied by this concept and on that note, would not 
terminate life, except perhaps as the only means to justly secure life. Thus, by this concept they would feel bound by their social ethics not to kill human beings or reluctantly do so even if that would secure their lives. What is implied here is that the first instinct that would define a social group that values human life would not be the instinct to kill but to protect, enhance and negotiate life to serve for more and better lives. There would be more urgency to safeguard the life at hand rather than to eliminate it. Finally, those who hold (g) a sense of the past would often not be too quick to venture into the unknown and would be cautious of the consequence of such actions as war. They would always be prompted to recall the positive bond that have held them together with other social groups in the past and apply this to promote peace.

Thus, a review of the substance of the African worldview as outlined in this work would reveal that many wars fought in modern Africa may not have been endorsed through the African worldview and would, for this reason have been largely "unAfrican" or non-African wars in the sense that they did not reflect or respect the substance of African worldview. Many of these wars were severe, total and what could be called 'allout wars' (interpreted to mean wars that aimed at total destruction of all citizens), that showed no respect for life. Indeed they bore more of the marks of people whose worldview approved aggression than those whose worldview approved peace and communitarian ethics. Some of the wars involved distant communities and nations who were hired to do large scale destruction of lives and properties. This does not mean that there were no wars in traditional Africa. Apart from those wars that were fought because of religious imperialism, such as those waged by Fulani Jihadists in West Africa, there were those that were influenced by sheer expansionist policies of several kingdoms and empires in pre-colonial Africa, such as the Zulu wars of Southern Africa and the Igala wars of North Central Nigeria. Other wars include "the battles of Toubakouta (1887), Musaija Mukuru Hill (1894), Rwempindu (1894), Atbara (1898)" (cited in Uzoigwe 1975: 479).

As it pertains the Fulani wars, it should be noted that these wars cannot be strictly called African wars going by the provisions of this work. This is because the wars had a colonial character in the sense that they were waged to enforce Islamic religion and code on the indigenous peoples of northern Nigeria or at least to enforce a pattern of belief different from what they had -although it also had a political dimension since it culminated in the enthronement of Emirs. In the case of other wars outlined, they are exceptions that will prove the theory that there were unjust wars in Africa but that there are principles that could be applied to distinguish just from unjust wars.

A crucial observation however needs to be made. A number of these wars were fought after European colonisation of Africa and this raises the doubt on whether they were indeed grounded on African ethics of war and warfare or were grounded on western ethics of war. Indeed, it would need a more profound interpretation of these wars to understand whether these wars were African wars in the ethical sense of the term (defined as wars that were motivated and fought in defence of African ideals and values). Negritude, one of the first post-colonial ideology that sought to account for African social ethics, holds that social relations in Africa amount to fellow feeling such as "I feel the other, I dance the other". If this ideology is considered and found valid, it is doubtful how this could lead to a worldview that can encourage or promote war as a social value. Ali Mazrui (1979: 52) the renowned African scholar submits that "the gods of Africans were majorly gods of war hence the ruthlessness of war in Africa". Yet the fact that the same author argues that Africans have a short memory of hatred (Mazrui 1996:17) appears to question this submission since a war-like attitude would have to be one that is founded in enduring ethics of hatred or at least one that cannot accommodate the principle of 
tolerance or short memory of hatred. An interpretation could however be made to accommodate the seeming contradiction implied in Mazrui's claim. Every African community has a way of honouring and remembering their heroes and heroines. Many of the heroes and heroines turn out to become deities in the process, who would always be invoked for protection against physical and spiritual harm. Since calamities are seen as a form of negative force and power that is capable of annihilating communities, the deities are supposed to have a stronger force and power to counter them, and are imbued with prayers, rites and rituals to exhibit these virtues, hence the warlike virtues that are associated with these gods and deities.

A summary of this section of the work shows that the effort to locate the idea of just war by exploring the substance of African worldview would show that Africans had social values that promoted peace far stronger than those that encouraged war; that they had a weak disposition to war as an option for social engagement; and that their worldview favoured peace rather than war. The implication of this is that war could only emerge as an option to oppose any force or measure that attempts to counter this worldview which encouraged peace and social cohesion. To further advance positions that explain the just war in the African context, I will discuss the nature of war in Africa. I argue that the nature of war and the manner of its execution can help illustrate the idea of just war in African thought scheme. To do this, I will (a) rehearse the process for peaceful resolutions of conflict, the failure of which leads to war in Africa and (b) discuss the method and means of executing wars when peace fails. Finally, I will discuss (c) the goal of wars in Africa. These options, I believe, can bring out the principles and ethics of conduct through which the idea of just war can be gleaned in African thought scheme. In doing this I will draw illustrations from instances of war in traditional Africa while drawing more from the Igbo instance that I am more familiar with.

\section{LOCATING AN AFRICAN THEORY OF JUST WAR THROUGH THE NATURE OF WAR IN AFrICA}

Before a war is declared in traditional African society, there is often a long effort at reconciliation of the dispute through intense deliberation. This is rooted in the fact that conflict is seen as the violation of the ontological harmony and the violation of the communal bond and social ethics of the people which should be averted. This is because of the organic link between the individual and the community. In an African setting, the state finds its origin in the communal ethics of the people as a result of which citizenship of a given state finds its origin in a certain level of loyalty to the community wherein the state is raised. There would have been community or at least the likelihood of the emergence of communal ethics among a people before the concept of the state gains legitimacy. Hence, there is an inherent moral, social and political need to belong to a community, as a result of which an individual cannot singularly claim loyalty to the state and employ all state apparatus against the community and still be qualified to be called a worthy citizen of the state. This is because citizenship is by a formal adoption by the community and not essentially by right of birth as it obtains in the modern state. Given then that the community is the basis on which citizenship and social belonging is measured, the community as an important institution is a critical agent in mediating in conflicts.

Thus, should there be a major crisis among a social group in Africa, the first response is often to lay a foundation for peace through deliberation and mediation among and for the communities involved through the mediatory role of other communities. The position is implied in the Igbo proverb which states that "na madu abo gburu onwe ha bu na onye ato anoghi ya": "that two people fought to kill each other is because a mediator 
or third party was not there". In the course of the mediation, the nature of the conflict is often discussed and the means to achieve peace agreed upon. Following this, adequate retribution is demanded from the wrong party, which could include but is not limited to restitution, fine, enslavement, exile, etc. Any of these could be paid by the guilty party to avert conflict or war. War is held to imply a total severance of peace and destruction of the physical and spiritual equilibrium on which the African state functions and for this reason efforts are made by all means to avert and avoid war and restore peace.

To achieve this principle of Harmony, Reconciliation and Restitution is sought through dialogue in peace panel. Effort is made to locate and apply people with the virtue of exceptional integrity by locating those who are distinctly known for their quality of thought, sagacious disposition and a distinct love for truth, to achieve a credible and productive dialogue. Among the northern Igbo (the Nsukka and Isi-Uzo area), those who possess this quality -those with impeccable character and integrity and qualified to volunteer facts and truth on such urgent matters of communal need and interest- are known as Akamugha. Such distinct members of the community are nominated from the two aggrieved communal groups to deliberate on the conflict in question and speak on behalf of the communities in dispute. It is expected that they would talk until issues are resolved amicably in line with the ethics of consensus in African thought. It is the failure of this peace process that leads to war.

In African traditional society, wars are mainly fought by able-bodied men, in particular hunters, who are held to have acquired some experience in the art of shooting. This claim is supported by the Igbo proverb which states that "nwoke lucha ogu,nwanyi enwere akiko": "men fight the war but women tell the story". However, this duty does not exclude them from their duty to the family. Those who are shortlisted for wars are also expected to cultivate their farm. The methods and means of executing wars include spears and arrows and other local weapons and resources such as charms and amulets, and this was the case until the introduction of guns into Africa. Goody (cited in Uzoigwe 1975: 474) observed that three military technologies were applied during the West African wars: "(i) bow and arrow, (ii) spear and sword, (iii) horse and gun. He argued that this could be located in such configuration as to whether the groups involved in the wars were "acephalous societies", "states", "savannah", "coastal states", or "grassland" (Uzoigwe op. cit.). The import of this is that military culture was defined and directed by environmental factors such as the weapons that could be sourced from the environment. However, the point to note is that these weapons of warfare, with their limited ability to destroy, caused less damage and causalities, at least in comparison with weapons of warfare that were introduced after colonialism and which have had massive destructive capacities.

In addition to applying these weapons, diviners and medicine men were also applied as weapons of war in Africa (for more details, see Ukpabi 1974: 215). They were applied to know the mind of the gods and to seek their support for conquest. In addition, medicine men were employed to produce charms that could facilitate victory. A particular war which this author is in a position to cite is the instance of war that involved two communities in what was then held to be Nsukka zone, of Eastern Nigeria in 1977. A primary witness of the war stated that diviners and medicine men were consulted and applied and that as the war was being executed, diviners and medicine men were constantly making incarnations for success. The summary view of this section is that the methods and means of war in traditional African societies involved physical and spiritual means, as can be illustrated from the belief ethic of the people.

War in African thought has a strong ethical demand and it is for this reason that war in traditional African societies does not often lead to maximum destruction as it 
is the case in modern wars. Modern warfare in Africa appears to support the wholesale destruction of the enemy by total war in which all the enemy's territory, property and population are attacked with unlimited force. This option of waging war supported by scholars such as Clausewitz (cited in Chinweizu 2015) is arguably behind such WWII horrors as the fire-bombing of Coventry, Dresden and other cities as well as the atom-bombing of Hiroshima and Nagasaki. Although this is not acceptable to the modern theory of just war, it must be noted that this has assumed a common feature of modern warfare in several parts of the world, including Africa, something that have remained alien to the African idea of war. A counter view could be posited that war in Africa did not cause maximum causalities apparently due to the absence of professional militaries. But there are strong positions that counter this point of view. Indeed the view that traditional African societies did not have professional armies is debatable. Johnson (in Uzoigwe 1975:471) holds the view that wars in pre-colonial Africa did not engage professional soldiers (perhaps because there were no distinct training schools for this), Ukpabi (1974: 200) believes that in well-established kingdoms such as Dahomey, Ashanti and Buganda "there existed a core of professional soldiers [..] the Dahomean standing army was estimated at 1200 in 1845 " (op. cit. p.203).

Several arguments can be advanced to resolve the hypothesis of whether there were professional soldiers in Africa or not. Several kingdoms and empires in Africa, south of the Sahara, were created through conquest. In Nigeria, there were the Oyo Empire, the Benin Empire, the Kwarafa Kingdom, etc. These empires achieved their expansionist drive through organised military conquest. Thus, the claim is that such conquest could not have been possible without military professionalism. But a possible objection could be further made that if such professionalism obtained, it would also imply that there were other co-professionals whose duty would have been to compliment the military. For instance, there would have been professional cooks who cooked for the military or professional farmers whose duty were to provide food for the families of soldiers or professional military technologists. Although Ukpabi (ibidem p. 206) held that women assisted soldiers at wartime, this claim does not provide much ground to defend the view that there were professional soldiers in traditional African societies and that professionalism was an important aspect of wars in Africa.

Perhaps a better way to resolve this debate is to calibrate wars in Africa into defensive wars and offensive wars. In this sense, defensive wars imply wars fought to defend the safety of the community and uphold the social ethics that bind the people together. Such wars often raised soldiers from the young men of the community, and this, I submit, predominated among the wars in traditional African societies. It is also wars such as these that are implicated in this work because they are models of just war. Offensive wars, on the other hand, are wars waged for expansionist reasons such as wars that were waged by the big empires and kingdoms of Africa. These wars of aggression are by their nature unjust in the sense that they meant an unprovoked attack, and a violation of other communities and an unprovoked attack and violation of the community is unjust in African thought.

In the effort to locate how the idea of just of war can be located in African thought, I further consider how wars are declared in traditional African societies as well as the goals and aims of war. Wars are often declared through the elders and custodians of tradition and when this is done the goal of the war is often spelt out clearly. They often would include such desires as (a) to restore the integrity of the community, (b) to ensure compliance to a treaty between the parties involved by enforcing it, and (c) to achieve a proportional retribution for an injustice meted out to one side, which injustice has not been acknowledged and for which the offender does not show any form of remorse or readiness to pay restitution. These goals of war translate to what can be called the fundamental principles that stand at the heart of war in Africa, and to these I now turn. 


\section{LOCATING AN AFRICAN THEORY OF JUST WAR THROUGH THE FUNDAMENTAL PRINCIPLES OF WAR IN AFRICA}

From the preceding part of this paper it is possible to abstract some principles that underlie war in traditional African society from where the idea of just war can be located -by this is meant some of the ideals that defend the ethics of war. These principles severally appeal to the idea of right actions and hence stand to suggest the idea of a just war. Drawing from the nature of war in Africa, the means through which wars are fought, the measure of success in the war and the goal of wars in Africa, it is safe to suggest that the fundamental principles of war in Africa are: (i) the Principle of the last means of addressing a conflict, (ii) the Principle of Proportional means and end, (iii) the Principle of Participatory Pain, and (iv) The Principle of Harmony. Whereas these principles cannot be applied to all wars, they would usually apply to a war that arises from and defends the social and moral ethics of the African worldview and this is the war that in my view qualifies for a just war in African thought scheme. In addition, whereas some of these principles can be also be found in the principles of just war in western literature others do not.

While the earlier literature on just war theory were concerned with locating justice in relation to the cause and course of war -that is, jus ad bellum and jus in bello; recent literature have drawn attention to the cost of war -that is, how to ensure that the ethics of justice also reflects in the aftermath of war, apparently because the after-war-effect of war can also affect the quality of justness of the war. This position which is referred to jus post bellum (justice at the end of the war) recommends dignity of the defeated party and post-conflict order (Patterson 2007: 41) as additional principles that should define the just war theory. Similarly, the principle of jus in bello (justice in the conduct of war) has also emphasized the distinction between combatants and non-combatants (Brough, et al. 2007: 246) and the principle of proportionality (Dower 2009: 83) -that is, ensuring that the more good than harm would be achieved by executing war-, as additional values that should define a just war. A close study of these positions would show that some of them are implicated in an African theory of just war, however in view of the fact that the African did not consult western literature before voting for this notion of just war, it is valid to hold that they are African principles of just war -that is, principles of just war that evolved through African ethics and schemes of thought. Thus while the principles of African theory of just war itemized could be found in principles of just war that emanate from the western tradition, those itemized in (iii) and (iv) are considerably African and could be said to drive from the nature of war in traditional African society. I then proceed to explain these principles by illustrating them with the hope that by so doing, the claims on an African notion of just war would be better made.

By the principle of last means of addressing a conflict is meant that war in Africa is often seen as a reluctant option invoked when every other option has failed. By relevant option is meant that war is not the first option in resolving a conflict. As a result of this, communities in Africa do not opt for war as the first option when a conflict arises. There is often the effort to achieve peace through such measures as negotiation, mediation and arbitration. It is the failure of these that lead to war. In this sense war can be called a reluctant forceful approach to achieving peace. An illustration of this can be found in what can be called a forewarned approach to war in Africa. By the forewarned approach to war is meant that war could be such that soldiers "surround a village to be attacked by night, yet a sense of chivalry caused the warriors to defer attack until the enemy had been

given sufficient warning to enable them prepare for the battle" (Ukpabi 1974: 215). A second dimension of the forewarned approach to war is the scenario whereby the attacking force would discharge a few force on arrival then wait until for the enemy to 
get collected and come out of the town to fight before launching a full attack (Ukpabi op. cit.). Both acts, which are some features of war in Africa, speak of war in Africa as a last means to peace.

The second principle that defines and directs war in Africa is the principle of proportionality or proportional means and end. By this is meant that war is often executed in a manner that would provide for and make up for the harm that caused the dispute in question and lead to what can be called measured restoration. For this reason war is not meant to annihilate the other party. This principle explains why war in traditional African societies was not one of battles and head-on attacks but what Ajayi and Smith (cited in Ukpabi 1974: 215) calls "ambushes, skirmishes and feints". This also explains why there were often less causalities in war in traditional African society such that those who caused heavy causalities were compelled to donate people to the losing side. It also explains why war in Africa involved the use of weapons that could not cause much damage or record much causalities. Although it could be argued that the use of these weapons, such as swords, machetes, arrows and dane guns, had to do with poor development in military technology, it can also be argued that the relatively poor development in the direction of militancy was a result of the ethics of war in Africa that limited the harm desired of war.

The third principle that directs war in Africa is the principle of participatory pain. By this is meant that war in Africa observed such ethics that forbade the total annihilation of an opponent. The whole essence of war is to prevent an unjust treatment of one group by the other or unjust violation of the ethics of harmony. Hence the overall goal of war is to bring the other party to a level of recognising the right of the other group to exist and to be respected as a separate entity. For this reason war is not fought in a manner that makes it possible to annihilate the other but with recognition that the other is a community of human beings whose losses also amounts to negative feelings for the opponent. This principle is supported by the Igbo proverb which states that "nakala ogu anaghi adi ka olulu ya": which means "war does not often reflect the intensity of the preparation".

The fourth principle is the principle of harmony. By the principle of harmony is meant the need to achieve a form of metaphysical and physical equilibrium. These metaphysical and physical equilibrium demand some form of moral and spiritual order. African societies believe that a certain measure of moral and spiritual order is necessary for the functioning of the human community. This order enables all forces and agents to play their role and safeguard any one of their own. For this reason, war even if necessary could be employed to achieve this order. But in executing the war, there would be no need to do more harm than is necessary at war since this may often lead to another process of restoration. Hence, wars are fought, not for conquest and defeat, but to achieve a higher moral gain of reconciliation and reunion. Reconciliation is often held to be social, moral and ontological in the traditional African society. In traditional African societies, "morality is seen to be in an intimate relationship with the ontological order of the universe. Any infraction of this order is a contradiction in life itself and brings about a physical disorder, which reveals a fault" (Anyika 1988: 168). It is the desire to restore this ontological order, as captured by Anyika, that leads to war. This restorative demand and the need to achieve protection and secure the communal harmony is, in my estimation, the reason each community had gods and goddesses that were meant to protect the community and who were supposed to play defensive roles in the case of any harm done by other communities, even at war. This principle is so vital and fundamental to African social and moral worldview that it can be held that a just war in African thought amounts to one fought to maintain a certain level of physical and corporate harmony. 
From the positions so far made in this work, I propose that in the African worldview a just war amounts to war fought to restore, defend, or protect the corporate harmony of the community as constitutive of the people, the land, the resources, the ancestors, the gods, etc. Such a war would of necessity have a peace potential and power and would be measured by its ability to have allowed or created a space for reconciliation and harmony. This notion of just war is amply captured by the Igbo maxim "ogu eji ofo anu" translated to mean "a fight grounded on truth and justice" and by the proverb which says that "ogu eji ofo anu bu ogu mmeri" translated to mean "a fight grounded on truth and justice is one that wins". Ofo stands for truth, justice and life (Ejizu 1986: 156). Ofo is a sacred symbol of justice in Igbo thought. Thus to fight with ofo symbolically means to have all the relevant values, such as truth and justice, that would enable the ofo function to one's favour. Such fight or war would have a restorative objective and it is such an objective that makes it a just war, because it is an effort to restore the principles that ofo defends. To do otherwise is to invite the wrath of ofo and to invite the wrath ofo is to "buy a salt that knows no rain" (F. C. Ogbalu 1979: 47), as another expression has it. This is because the consequences are destructive. What this means is that fighting war without observing the ethics of wars outlined here could be counterproductive.

\section{CONCLUSION}

This work has tried to provide positions through which an African theory of just war can be understood. It has done so by articulating the methods, means and goals of war as well as principles that a just war in African context should defend. The work made enormous use of Igbo experience through narratives and proverbs that illustrate its position. This does not mean that the application of the Igbo ethno-cultural group suffices what can obtain in other ethno-cultural groups but that it serves as an illustration of war in African experience. Since the work is aimed at providing a theory that accounts for just war in African experience, the war also made use other narratives that go beyond the Igbo experience. Its major finding is that war in the African context can be read from the mode and manner it is executed. The work also submits that a just war in African experience makes adequate room for reconciliation and the further strengthening and extension of corporate harmony which serves as the highest social ideal in African thought. Further studies on just war in African thought could aim at applying this theory to evaluate the several wars fought in post-colonial Africa to weigh the African content of these wars (interpreted here to mean the principles harboured by war ethics in African thought and/or whether these wars were "unAfrican wars" -interpreted to mean wars that did not defend African principles of war). For instance, several wars fought in post-colonial Africa, such the Nigerian civil war, the Sudanese wars and the wars in Congo, are widely reported to have claimed millions of lives. It will be important to raise philosophical questions about these wars through an African perspective in the light of the submissions of this paper. This will serve to decolonise war and raise a more critical thought in matters relating to war and warfare. This will also add to provide alternatives in the effort to re-think war and promote the principle of peace.

\section{REFERENCES}

Achiriga, J. J. Alogoa, E. J. (2001) "Conflict Resolution: The Nigerian Perspective", KIABARA, Journal of Humanities, 7, 1.

Ajayi, J. F. A. and Smith R. (1964) Yoruba Warfare in the Nineteenth Century Ibadan, Cambridge Press.

Ajayi, J. F. A. (I965) "Professional Warriors in the Nineteenth Century Yoruba Politics", Tarikh, 1, 1, pp. 72-81. 
Anyika, F. (1988) "Ethics in Traditional African Religion", in I. T. K. Egonu (ed.), Readings in African Humanities: African Perspective in World Culture, Nigeria, Vivans and Vivans.

Armah, A. K. (1973) Two Thousand Seasons, London, Heinemann.

Awe B. (1973) "Militarism and economic Development in Nineteenth Century Yoruba" Warfare, Journal of African History, 14, 1, pp. 65-77.

Brough M. W, J. W. Lango and H. Van der Linden (2007, eds.) Rethinking the Just War Theory, New York, State University of New York Press.

Brukum, N. J. K. (1998) "Conflict and Conflict Resolution among the Nckumuru", Transaction of the Historical Society of Ghana, 2, pp. 39-47.

Chinweizu (2015) "A Dose of East Asia: Cultural Antidote for Black Africa's Eurocentrism - A theme in Niggerology", Paper presented at the International Conference on Asian Studies in Africa Conference organized by the Association for Asian Studies in Africa (A-Asia) with the International Convention of Asia Scholars (ICAS) and international Institute for Asian Studies, The Netherlands, held at the University of Ghana Legon, September 23-27.

Campbell, Colin (1987) "Starvation Was the Policy" New York Times, March 29 https://www.nytimes.com/1987/03/29/books/starvation-was-the-policy.html (Accessed November 2020).

Cordeiro-Rodrigues, L. \& Danny Singh (2019, eds.) Comparative Just War Theory. An Introduction to International Perspectives, London, Rowman and Littlefield.

Crowder, M. (ed.) (1971) West African Resistance: The Military Response to Colonial Occupation, London, Hutchinson.

Dan, J. (1987) The Brutality of Nations, New York, Alfred A. Knopf.

Dower, N. (2009) The Ethics of War and Peace: Cosmopolitan and Other Perspectives, Cambridge, Polity Press.

Ejizu, C. I. (1986) Ofo: Igbo Ritual Symbol, Enugu, Fourth Dimension Publishing Co.

Ezeh, Mary-Noelle Ethel (2019) "Starvation and Relief Operations in the Nigeria/BiafraWar: The Role of Religious Organizations and the Local Population" in The Nigeria/Biafra War: Genocide and Politics of Memory, Cambria Press. https://www.researchgate.net/publication/333356998 (Accessed November 2020).

Ezenwoko, F. A. \& Osagie, J. I. (2014) "Conflict and Conflict Resolution in Pre-Colonial Igbo Society of Nigeria”, Journal of Studies in Social Sciences, 9, 1, pp. 135-158.

Fagothey, A. (1963) Right and Reason, (C.V. Mosby, U.S.A.).

Francis, D. J. (2006) "Peace and Conflict Studies and Conflict Studies: An African Overview of basic concepts", in Shedracks Gaya Best (ed.), Introduction to Peace and Conflict Studies in West Africa, Ibadan, Spectrum, pp. 10-24.

Holloway, Joseph E. (ND) The Biafran Civil War: The Politics of Hunger and Starvation http://slaverebellion.info/index.php?page=the-biafran-civil-war-the-politics-of-hungerstarvation (Accessed November, 2020).

Karugire, S. (1972) "Succession wars in precolonial kingdom of Nkore", in Ogot, B. A. (ed.), War and Society in Africa. Ten Studies, London, Frank Cass, pp. 9-34.

Metz, T. (2007) "The Motivation for 'Toward an African Moral Theory", South African Journal of Philosophy, 26, pp. 331-35.

Metz, T. (2019) “An African Theory of Just Causes for War", in Luís Cordeiro"Rodrigues and Danny Singh (eds.), Comparative Just War Theory. An Introduction to International Perspectives, London, Rowman and Littlefield, pp.131-155.

Mbiti, J. (1969) African Religions and Philosophy, Oxford, Heinemann Educational Books. 
Mazrui, A. (1996) "Africa in the Twenty-First Century: Problems and Prospects", Annual Distinguished Lecture of the Institute of Governance and Social Research, Jos, Nigeria.

Mazrui, A. (1979) The African Condition, Ibadan, Heinemann.

Momoh, C. S. (1989) "Philosophy in African Proverbs", in C. S. Momoh (ed.), The Substance of African Philosophy, African Philosophy Projects Publications, pp. 231255.

Mudge, George Alfred (1970) "Starvation as a Means of Warfare", The International Lawyer, 4, 2, pp. 228-268.

Ogbalu, F.C. (1979) Omenala Igbo: The Book of Igbo Custom, Ibadan, University Publishing Company.

Ogot, B.A. (1972, ed.) War and Society in Africa. Ten Studies, London, Frank Cass.

Okeja, Uchenna (2019) "War by Agreement", Journal of Military Ethics, 18, 3, pp. 189203.

Onwubiko, Oliver (1991) African Thought, Religion and Culture, Enugu (self-published).

Patterson, E. (2007) "Jus Post Bellum and International Conflict: Order, Justice and Reconciliation", in M. W. Brough, J. W. Lango and H. Van der Linden (eds.), Rethinking the Just War Theory, New York, Albany, State University of New York Press, pp. 35-52.

Smaldone, J. P. (1975) Warfare in Sokoto Caliphate: Historical and Sociological Perspectives, Cambridge, Cambridge University Press.

Ugochukwu, O. (2006) "Dispute in Igbo Society: The Case of Obowo in Imo State", Journal of Igbo Affairs, 2, 1.

Ukpabi, S. C. (1972) Military Involvement in African Politics: An Historical Background New York, Conch Magazine Ltd.

Ukpabi, S. C. (1974) “The Military in Traditional African Society”, Africa Spectrum, 9, 2, pp. 200-217.

Uzoigwe, G. N. (1975) "Pre-colonial Military Studies in Africa", The Journal of Modern African Studies”, 13, 3, pp. 469-481.

Uzoigwe, G. N. (1974) "The Military in Politics in Pre-colonial Africa: A Case Study of the Interlacustrine States of Bunyoro Kitara and Buganda”, Annual Meeting of the American Historical Association, Chicago, 28-30 December 1974.

Ugwuanuyi, L. O. (2008) "The Idea of Democracy in Igbo Culture of Nigeria", in Ike Odimegwu (ed.), Nigerian Democracy and Global Democracy, Nnamdi Azikiwe University Awka UNESCO Philosophy Day Publication, Awka, Fab Educational Books, pp. 172-183.

Ugwuanyi, L. O. (2006) "Traditional Igbo Politics in the Context of Eziokwu Bu Ndu", in Nkeonye Otakpor (ed.), Eziokwu Bu Ndu Truth is Life, Uniben Studies in Philosophy, Ibadan, Hope Publications, pp. 95-104.

Ugwuanyi, L. O. (2020) "Uncovering Needs in African Thought Through Igbo Proverbs on Lack, Care and Duty", in Motsamai Molefe and Chris Allsobrook (eds.), African Political Philosophy of Needs, Palgrave Macmillian (forthcoming).

Ugwuanyi, L. O. (2020) "Exploring the African Philosophy of Humour through Igbo Proverbs on Laughter", The Southern Journal of Philosophy, USA (forthcoming)

Webster, J. B. (1972) "The Civil War in Usuku”, in B. A. Ogot (ed.), War and Society in Africa. Ten Studies, London, Frank Cass, pp. 35-64. 